\title{
Pre-Service Teachers' Beliefs about Language Learning Inventory (BALLI) on Bilingualism: Getting Insights to Developing Knowledge
}

\author{
Jian Liu ${ }^{1} \&$ David Rutledge ${ }^{1}$ \\ ${ }^{1}$ School of Teacher Preparation, Administration, and Leadership, New Mexico State University Las Cruces, The \\ United States of America
}

Correspondence: Jian Liu, School of Teacher Preparation, Administration, and Leadership, New Mexico State University Las Cruces, The United States of America.

Received: June 18, 2020

Accepted: August 7, 2020

Online Published: August 10, 2020

doi: 10.5539/elt.v13n9p30

URL: https://doi.org/10.5539/elt.v13n9p30

\begin{abstract}
The goal of pre-service teacher (PST) programs is to provide students with pragmatic working experience and pedagogy that they need for becoming eligible teachers. In a bilingual classroom, however, some perspectives about second language learning (SLL) held by PSTs are too arbitrary. To assist PSTs in developing concepts of second language acquisition as related to educational settings and to cultivate PSTs' burgeoning educational beliefs, this study was conducted using the Beliefs About Language Learning Inventory (BALLI). Seventeen PSTs who were enrolled in a university located along the southern U.S. border provided data for the present study. Three of the 27 belief statements included in the BALLI survey were critically analyzed. This critical analysis explored why certain PSTs' beliefs about second language learning diverged from social reality at schools. Based on the analysis and results from our findings, suggestions about how to improve the bilingual education for PSTs are provided.
\end{abstract}

Keywords: BALLI, pre-service teacher, second language learning, social and cultural context

\section{Introduction}

Pre-service teacher (PST) education is a course of study offered to university students before they participate in the K-12 teaching profession. There have been various studies concerning pre-service teacher education: improving class practice (Soccorsi, 2013; Vision, 2001; Goff-Kfouri, 2013); adjusting curriculum design (Gorth and Bergner, 2005; Woodcock, Hemmings, \& Kay 2012; Mooi and Mohsin, M., 2014); and suggesting policy implementation (Frimming, \& Willis, 2017; Lattimer, 2012; Lin, Childs, and Zhang, 2016; Labone, Cavanagh, and Long, 2014). Grijalva \& Esparza (2013) identified PSTs' beliefs about English language teaching and learning at different stages of instruction, while İnceçay (2011) explored the effects of PSTs' language learning beliefs on their future teaching practices. More directly, Argaman \& Vaknin-Nusbaum (2016) recognized the changes in PSTs' language knowledge regarding their phonological and morphological awareness after PSTs have learned about applied linguistics. Furthermore, Andrews (2001) and Ellis (2012) claim that teachers developing language awareness in TESOL has a pedagogical effect of such awareness on teaching practice. Lastly, Durgunoglu and Hughes (2010) explained that a teacher's preparedness for ELLs relies on self-efficacy, attitude, perceptions, and knowledge.

The above contributions from previous studies, which are related to beliefs about language learning on improving PST programs, serve as a support for our goal of including bilingualism and ESL content in PST education. We strive for understanding how PSTs develop skills for negotiating two or more languages in classroom settings. Specifically, considered as one of the indispensable prerequisites for PSTs before their career path begins, the beliefs about second language learning held by PSTs require further exploration and examination. Providing opportunities to develop PSTs' beliefs about second language acquisition can influence how we prepare PSTs for curriculum design, teaching practices, interpersonal relationships between teacher and student, and K-12 students' psychological development. The consequences of how a teacher instructs students without considering unexamined arbitrary beliefs can be detrimental and may impose unexpected negative influence on both students and their parents. The purpose of this study is to understand PSTs' beliefs about second language learning in a bilingual classroom and to explore the potential social and cultural reasons why PTSs develop beliefs about language learning. 


\section{Literature Review}

\subsection{Bilingual and Bilingualism}

The definition of bilingualism has been elaborated over the past decades (Baker, 2011; Ng, 2015; Bloomfield, 1935; Macnamara, 1967; Mohanty, 1994; Titone, 1972). Bilingualism, although seemingly impossible to be accurately defined, can still attain its connotative and denotative interpretations from elicited perspectives (Baker, 2011). According to $\mathrm{Ng}$ (2015), bilingualism could be described as people who speak two languages in the simplest terms. More recently, the concept of Translanguaging (Esquinca, 2014) is prominent in discussing how bilingualism is defined. For this study, we consider these definitions as they relate to how PSTs express beliefs about language learning in their preparation of working in bilingual classrooms.

In the current school context along the U.S. and Mexico border, there is an expectation that teachers be prepared to teach learners from complex linguistic backgrounds. The bilingual school settings, including dual language programs, strive to follow best practices for bilingual learners. In PST programs, the inclusion of ESL methods, second language acquisition, and issues for bilingual learners' coursework is part and parcel to completing a degree for teacher licensure. Only by having comprehensive knowledge about the concept of bilingualism and the benefits that bilingualism brings to teaching practices, can PSTs be more prepared for the classroom. And, it is from within this teacher education context that PST beliefs about language learning can inform university program practices

\subsection{BALLI}

The Belief About Language Learning Inventory (BALLI) designed by Horwitz (1988) was applied to evaluate PSTs' beliefs of learning a foreign language (See Appendix A). The 5-point Likert Scale (1932), ranging from ' 1 -strongly agree' to ' 5 -strongly disagree', was employed to answer the 34 statements in the BALLI. Horwitz (1988) used this instrument to gather data concerning the beliefs of students studying commonly taught languages (CTL) in the U.S. and beliefs of ESL and CTL teachers (Kuntz, 1996). As demonstrated by Kuntz (1996), three distinct BALLIs are in use today: one for ESL students $(1984,1987)$, another for foreign language teachers (1985), and a third for foreign language students $(1988,1990)$.

After Horwitz conducted the study at the University of Texas at Austin, BALLI was also further employed by Yang (1992) at six universities in Taiwan, Park (1995) at two universities in Korea, and Truitt (1995) at Yonsei University in Korea as three examples of using this instrument for investigating the beliefs of English language learners in foreign countries. Furthermore, language learners whose target language was not English were also interviewed by employing Horwitz's instrument. (Horwitz, 1988; Kuntz, 1996b; Smith, 1989; Tumposky, 1991; Finneman, 1990; Mori, 1999). Diverging slightly from the study purposes for which the BALLI were previously applied, the present study investigated PSTs in terms of their language beliefs and working information in bilingual settings.

\section{Study Methods}

\subsection{Participants}

The purposeful criterion sampling method was utilized to select participants for the present study. Purposeful sampling is a technique widely used in qualitative research for identifying and selecting information-rich cases for the most effective use of limited resources (Patton, 2002). Furthermore, Patton (2015) elucidates that "the logic and power of qualitative purposeful sampling derives from the emphasis on an in-depth understanding of specific cases: information-rich cases. Information-rich cases are those from which one can learn a great deal about issues of central importance to the purpose of the inquiry, thus the term purposeful sampling" (p. 53). Purposeful sampling for this study involved identifying and selecting individuals that "were especially knowledgeable about or experienced with a phenomenon of interest" (Cresswell \& Plano Clark, 2011).

The present study examined selected PSTs' beliefs about language learning after participating in elementary-level classrooms and supporting teachers in a dual language school context. The participating PSTs were taking a course related to issues of K-12 bilingual learners in the bilingual classroom environment. The PSTs' academic coursework intends to prepare them to become K-12 teachers. Therefore, by synchronizing the data collection with weekly teaching activities, participants' reflections provided additional insights into their developing language learning beliefs. The participants, 15 females and one male were monolingual English $(\mathrm{n}=7)$, bilingual Spanish-English $(\mathrm{n}=7)$, or bilingual Indigenous Language-English $(\mathrm{n}=1)$. 


\subsection{Data Context}

Via the BALLI survey (Appendix A), the main purpose of this study was to probe the PSTs' perspectives in relation to language learning and the social \& cultural reasons hidden behind these perspectives. At the beginning of the semester, the PSTs were placed in a classroom at a local elementary school in which the majority of students were Spanish-English speakers. During class sessions, the PSTs were invited to assist teachers in in-class activities and support teaching tasks. The BALLI survey was administered at the end of the semester and it took the participants about 20 minutes to complete.

\subsection{Validity and Transferability}

First, to ensure the trustworthiness of the data, we analyzed the data by employing 'triangulating analysis' (Patton, 2015, p. 665), in which we independently analyzed the data shown in the questionnaires and compared our findings in meetings afterward.

Secondly, the implementation of 'member checks' was used to enhance the validity of our study. Maxwell (2013) argues that member checking is "the single most important way of ruling out the possibility of misinterpreting the meaning of what participants say and do and the perspective they have on what is going on, as well as being an important way of identifying your own biases and misunderstanding of what you observed" (p.126-127). The member check was conducted in the form of a weekly diary written by the participating PSTs. Their beliefs about SLL while participating in K-5 bilingual classrooms were reflected in their diaries. More importantly, participants' diaries were updated weekly, which means the changes in these PSTs' beliefs regarding language learning were compiled. The compilation recorded how PST's beliefs about ELLs changed along with their ongoing teaching activities in the immersed bilingual environment.

Lastly, we employed the theory of 'working hypothesis' (Cronbach, 1975) to enhance the validity of the present study. Cronbach expresses that, to validate the transferability of findings, a working hypothesis can reflect situation-specific conditions in a special context. For this study, PSTs developed their knowledge and beliefs about language learning from coursework and current practitioners can be offered as guidance in making instructional decisions in their future classrooms. As mentioned above, the BALLI is widely used in ESL fields and the statements in the BALLI represent many ESL teachers' beliefs. To some extent, our findings, by considering the responses to the statements in the BALLI, will inform PST educators about how their decisions, concerning their practices, are connected to bilingual learners.

\section{Result and Discussion}

As shown in the BALLI questionnaire (Appendix A), the participants' responses to four statements in the BALLI survey were more revealing than the others. As a reminder, the BALLI scale ranged from $1=\mathrm{SA}$ to $5=\mathrm{SD}$. First, statement \#5 (It's important to speak a foreign with an excellent accent) had an average of 3.87/5, which revealed the majority of participants believed that an excellent accent did not possess pragmatic significance in the process of second language acquisition. Secondly, participants' responses to statement \#17 (Women are better than men at learning foreign languages) with a mean value 3.81 reflected their perception that female students did not outperform male students in their capability of second language learning. Thirdly, with an average score of 1.62, participants' responses to statement \#21 (If PSTs learn to speak a second language very well it will help them get a good job) indicated being bilingual was an advantage for potential employability. Finally, with a mean value of 4.19, the participants' feedback to statement \#23 (People who are good at math and science are not good at learning foreign languages.) exposed a fact that PSTs believed someone's ability in math and science should not limit how they are considered regarding the potential development of a second language.

The three statements (\#5, \#17, \& \#21) with revealing responses piqued our interest the most. Specifically, we wanted to consider how those strong beliefs held by PSTs aligned with social reality and current research findings; how our research findings supported these PSTs' beliefs with sufficient social and cultural context; how the connotative and denotative factors caused the formation of such misconceptions; and finally, what the possible pedagogical and curricular adjustments could be made to facilitate PST program designs in preparing bilingual learners. With the limitation of the selected elements in the study, the answers to these three BALLI statements are discussed below.

\subsection{Statement \# 5: Accent Significance}

Based on previous research, it is suggested that accent in second language acquisition possesses both social and cultural importance to a considerable extent. In contrast to our participants' responses to Statement \#5 (3.87/5) that accent in language learning is not significant, previous research findings value the importance of accent. First, in the sociolinguistic context, accents not only define people but also play an important part in showing 
their membership to a specific speech community (Aydemir, 2013). Becker (1995) asserts accent identifies one's regional, original, national, and ethnic identity, regardless of the language they speak. Kumagai (2013) further elucidates that social power is differentiated due to the divergence of accents. Moreover, Kinginger (2004) states that learning a second language often results in negotiating, constructing or reconstructing identity because language learning incorporates both a formal set of rules along with the culture.

The PSTs in this study underestimated the significance of accent in language learning. And, this perception of accent could be attributed to their developing understanding of bilingualism. Any language, at its inception stage, was to create coherent messages and exchange information (Halliday, 1994; Halliday \& Hasan, 1976; Hunston \& Thompson, 2000), so communication becomes possible. On many occasions, accent hinders the potential effectiveness of communication but will not eradicate people's incentives to communicate. In daily communication, speaking a language with its native accent does not matter as much as utilizing the language to send messages. Nevertheless, the threshold is elevated when an accent is viewed as part of an individual linguistic background applied to teach the practice in classrooms (Kumagai, 2013). Scovel (1969) found that junior high school students, after hearing one sentence only twice, could judge whether a speaker was a native-born American with $85 \%$ accuracy. Such a judgment can be viewed as a benchmark to evaluate a teacher's linguistic background. Most second-language learners tend to believe their learning result is more satisfactory if they are taught by native speakers because they can speak the language better and use it in a more natural way to communicate in class (Árva \& Medgyes, 2000).

The PSTs' exposures indicated that they were not concerned with the significance of accent in language learning, which can be related to the classroom settings they participated in during the semester. All the PSTs in this study were accustomed to bilingual settings and most of them spoke English as their first language or were bilingual speakers. The PSTs' language dominance in English helped them overcome the obstacles to understanding the students' meaning in their practice classrooms, even if the students spoke English with an accent. Many of the K-5 students spoke Spanish as their first language, so the Spanish language also assisted successful communication between the PSTs and students, which might be another reason why the PSTs neglected the significance of accent.

\subsection{Statement \#17: Women are Better in Language Learning}

The PSTs' responses to statement \#17 (3.81/5) proved their insistence that there is no intellectual discrepancy between female and male students in the process of their second language acquisition. However, there is a commonly held belief that the rate of female teachers and students developing a second language proficiency is higher than their male counterparts. Social and cultural attributes are intertwined together, attributing to the commonly held belief of gender as an indicator language development. Some academics take a position that gender differences are culturally shaped and defined by the individual's sense of oneself as 'masculine' or 'feminine', and that gender identity is not fixed and can be in a state of constant flux (Butler, 1990; Humm, 1989; Weedon, 1987).

It is noteworthy that other scholars found that intellectual discrepancy between genders does exist due to the characteristics of studied subjects (Anastasi, 1985; Sunderland, 1998; Powell and Batters, 1985; Burstall, 1975; Boyle, 1987; Ehrlich, 2001). According to Anastasi (1985), girls may learn to meet problems through social communication from early childhood, while boys may learn to meet problems through spatial exploration and independent action. Therefore, it is reasonable to propose that due to the stress on social interaction the language classroom has been described as a "girls' domain" (Sunderland, 1998). Moreover, some studies reported that girls tend to outperform boys in language learning (Powell and Batters, 1985), which could be since girls comport themselves differently from boys (Sunderland, 1998). Many SLA theorists also believe that female learners show possible superiority in their second language learning process (Burstall, 1975; Boyle, 1987; Ehrlich, 2001).

The unbalanced gender composition of our participants was the limitation of the present study, which explained why the PSTs' attitude on this statement tilted considerably. When referring to the experience of language learning influenced by gender issues, our data supported the opinions from both male and female were more elusive. The findings on this statement in the BALLI might be different if more male PSTs participated. Another reason might be the language environment the PSTs are immersed in. In the present study, the participants were immersed in an English-Spanish bilingual classroom along the southern U.S. border. In this border region, English is the major language used by people in their school life. However, Spanish is also widely used by the people living in this area due to the geographic and demographic particularities. The easy accessibility of the bilingual language environment helped PSTs engage in the two languages naturally and provide them a ground 
to neglect the intellectual factor that was manifested as a discrepancy between genders in previous research findings.

\subsection{Statement \#21: Being Bilingual Means a Good Job}

Statement \#21 in the BALLI are aligned with the PSTs' response (1.62/5) that being bilingual guarantees a good job. However, considering demographic data is necessary when relating bilingualism to individual career prospects. Scamman (2018) revealed that 53 million people, among whom 41 million are native Spanish speakers and approximately 11.6 million are bilingual Spanish Speakers, live in the United States. More people are speaking Spanish in the United States than in Spain (47 million speakers) and Colombia (48 million speakers). Also, by 2050, the United States is expected to have 138 million Spanish speakers, making it the largest Spanish-speaking country in the world. Therefore, the increasing number of Spanish speakers will not necessarily guarantee a good job, based on theories of supply and demand.

Adam Smith's theory of the invisible hand (1759) vividly articulates the career prospect for the English-Spanish bilinguals in the United States. According to Smith (1759), the relationship between supply and demand in the free-market economy shows that merchandise will become difficult to sell and its price will be very low when the merchandise is overly supplied. English is typically considered as the first and official language in the United States. Meanwhile, the population of Spanish speakers in the U.S. is also very large. Following the concept of merchandise competition in a seller's market, when the availability of certain merchandise in the market is redundant, the selection standard will wind up gradually. This theory of supply and demand may help to explain the potential challenges for Spanish-English bilinguals trying to secure a good job in the U.S. market. For the border regions in the U.S., if human resource officers are fortunate enough to have an oversupply of bilingual speaking employee candidates, the market will be oversaturated and employment will be influenced accordingly.

Moreover, defining a typical 'good job' is a technical problem and may vary individually. According to a definition made by Public Community Venture (2016), a good quality job should comprise five of the following facets: a living wage, basic benefits, career-building opportunities, wealth-building opportunities, and a fair and engaging workplace. For our participating PSTs, career opportunities are more nuanced because of the border context.

The PSTs in this study deemed being bilingual as an advantage for getting a good job because the social and economic environment along the southern U.S. border areas does not mirror the macro-social and economic reality nationwide. Along with the border areas, a considerable number of K-12 students are from families whose parents are the first generation of Spanish speaking immigrants. The Spanish language is the major language spoken by the children living in these areas before they grow to school age. When these children begin their formal schooling with prominent Spanish proficiency, becoming bilingual arises as an imperative for teachers to be able to successfully communicate with the children and their parents because the context for improperly communicating with the young students in the class may not only make curriculum design and teaching the target language difficult to reach but it can also provoke racial tension at school. If PSTs know Spanish, they can reduce situations for miscommunication. However, alternately, the market demand for bilingual professionals is highly valued in U.S. border areas, and yet the availability of bilingual PSTs and in-service teachers is also greater than in other parts of the United States. Subsequently, the competition is greater for a teaching position along the U.S. border if a PST is bilingual in Spanish-English, therefore, obtaining the first satisfactory job can be challenging.

\section{Implications and Future Study}

\subsection{Representativeness of Participants}

First, we recognize the limitations related to the imbalance based on the gender identification of the participant pool. And, because the BALLI survey was completed at the end of the semester after the PTSs were immersed in the bilingual school setting, results did not allow for a comparison related to the influence a bilingual teaching practice could have on changing PSTs' beliefs. Additionally, we could have addressed more on the PSTs' beliefs based on their involvement in the bilingual classroom. In the end, the findings in this study revealed that the examined beliefs regarding second language acquisition are imperative to PSTs. Concurrently, a person's beliefs might be influenced by geographic, linguistic, cultural, and other undetermined factors. Therefore, future research should examine the beliefs of the bilingual PSTs who speak languages other than the two involved in this study. 


\subsection{Market Demand and Competitiveness of Bilingualism}

Spanish-English bilingualism is a buyer's market in the United States because of its large population. However, the market demand specific for bilingual educators in the United States and other countries can be investigated with a linguistic concern. Although the study exposes that it is challenging for Spanish-English bilinguals to secure good jobs in the United States, the situation along the southern border areas might be different because of the large population density of Spanish speakers. Understanding the market demand for bilingual teachers may help educators, policymakers, and researchers design curriculum interventions in a more realistic way. Additionally, the career path of PSTs in these areas might have significant implications for designing and revising PST programs with a consideration of geographic and demographic characteristics

\section{Conclusion}

The application of the BALLI and its findings in this study indicates that PSTs' beliefs are influenced by specific social and cultural contexts in which PSTs are involved. The dual-language school setting, as a practical teaching context where relationships between PSTs and students are established, supplies a space to examine the PSTs' beliefs. Regarding the improvement in PST programs, language use, especially bilingualism, should be discussed and contextualized as one part of curriculum design. Lastly, as for the bilingual advantage on the extent to which PSTs pursuing careers as educators can enjoy, the demographic and geographic factors should be taken into consideration.

\section{Acknowledgment}

The authors would like to acknowledge the PST participants and the administrators of the elementary school in the study.

\section{Disclosure Statement}

No potential conflict of interest was reported by the authors.

\section{References}

Anastasi, A. (1985). Reciprocal relations between cognitive and affective development-with implications for sex differences. In T.B. Sonderegger (Ed.), Psychology and Gender (pp. 1-35). Lincoln: University of Nebraska Press.

Andrews, S. (2001). The language awareness of the L2 teacher: Its impact upon pedagogical practice. Language Awareness, 10, 75-90. https://doi.org/10.1080/09658410108667027

Argaman, O., \& Vaknin-Nusbaum, V. (2016). Language awareness of teacher trainees, Journal of Language Teaching and Research, 7(1), 9-18. https://doi.org/10.17507/jttr.0701.02

Árva, V., \& Medgyes, P. (2000). Natives and non-natives teachers in the classroom System, 28(3), 355-372. https://doi.org/10.1016/S0346-251X(00)00017-8

Aydemir, A. B. (2013). The relationship between cultural identity and accent, M.A. Thesis. Retrieved from http://www.thesis.bilkent.edu.tr/0006355.pdf

Bacon, S. M., \& Finnemann, M. D. (1990). A study of attitudes, motives, and strategies of university foreign language students and their disposition to authentic oral and written input. Modern Language Journal, 74(4), 459-473. https://doi.org/10.1111/j.1540-4781.1990.tb05338.x

Becker, P. (1995). The etiology of foreign accent: Towards a phonological component of identity. Unpublished master's thesis, Southern Illinois University, Carbondale.

Bialystok, E., Craik, F. I. M., \& Freedman, M. (2007). Bilingualism as a protection against the onset of $\begin{array}{lllll}\text { symptoms of } & \text { dementia. } & \text { Neuropsychologia, } & 459-464 .\end{array}$ https://doi.org/10.1016/j.neuropsychologia.2006.10.009

Bloomfield, L. (1935). Language. London: Allen and Unwin.

Boyle, J. P. (1987). Sex differences in listening vocabulary. Language Learning, 37(2), 273-284. https://doi.org/10.1111/j.1467-1770.1987.tb00568.x

Burstall, C. (1975). Factors affecting foreign-language learning: A consideration of some relevant research $\begin{array}{llll}\text { findings, Language Teaching and Linguistic Abstract, 8, } & \text { 8. }\end{array}$ https://doi.org/10.1017/S0261444800002585

Butler, J. (1990). Gender Trouble: Feminism and the Subversion of Identity. New York: Routledge. 
Byram, M. (1997). Teaching and assessing intercultural communicative competence. Clevedon, UK: Multilingual Matters.

Clark, E., \& Paran, A. (2007). The employability of non-native-speaker teachers of EFL: a UK survey system, 35(4), 407-430. https://doi.org/10.1016/j.system.2007.05.002

Colson, T., Sparks, K., Berrige, G., Frimming, R., \& Willis, C. (2017). Pre-service teachers and self-efficacy: A study in contrast. Discourse and Communication for Sustainable Education, 8, 66-76. https://doi.org/10.1515/dcse-2017-0016

Cresswell, J. W., \& Plano Clark, V. L. (2011). Designing and Conducting mixed method research (2nd ed.). Thousand Oaks, CA: Sage.

Cronbach, L. J. (1975). Beyond the two disciplines of scientific psychology. American Psychologist, 30, 116-127. https://doi.org/10.1037/h0076829

Dawson, D., \& Sandrock, P. (2017). Conference presentation for the American Council on the Teaching of Foreign Languages.

Dodson, C. J. (1972). Language teaching and the bilingual method (2nd ed.). London: Pitman.

Durgunoglu, A. Y., \& Hughes, T. (2010). How prepared are US preservice teachers to teach English language learners? International Journal of Teaching \& Learning in Higher Education, 22, 32-41.

Ehrlich S. (2001). Representing Rape: Language and Sexual Consent. London: Routledge.

Ellis, E. M. (2012). Language awareness and its relevance to TESOL. University of Sydney Papers in TESOL, 7 , $1-23$.

Esquinca, A., Araujo, B., \& de la Piedra, M. T. (2014). Meaning-making and translanguaging in a two-way dual-language program on the U.S.-Mexico border. Bilingual Research Journal, 37(2), 164-181. https://doi.org/10.1080/15235882.2014.934970

Goff-Kfouri, C. A. (2013). Pre-service Teachers and Teacher Education. Procedia-Social and Behavioral Sciences, 93, 1786-1790. https://doi.org/10.1016/j.sbspro.2013.10.117

Grijalva, S. D. C., \& Esparza, E. R. (2013). Pre-Service Teachers' Beliefs about Language Teaching and Learning: A Longitudinal Study. Profile, 15(1), 81-95.

Groth, R. E. \& Bergner, J. A. (2005). Preservice elementary school teachers' metaphors for the concept of the statistical sample. Stat. Educ. Res. J., 4(2), 27-42.

Halliday, M. A. K. (1994). An introduction to functional grammar (2nd ed.). London: Arnold.

Halliday, M. A. K., \& Hasan, R. (1976). Cohesion in English. London: Longman.

Holliday, A. (2008). Standards of English and Politics of Inclusion. Language Teaching, 41(1), 119-130. https://doi.org/10.1017/S0261444807004776

Horwits. (1985). Beliefs About Language Learning Inventory. Horwitz, E. K. Using student beliefs about language learning and teaching in the foreign language methods course, Foreign Language Annals, 18(4), 333-340. https://doi.org/10.1111/j.1944-9720.1985.tb01811.x

Horwitz, E. K. (1988). The beliefs about language learning of beginning university foreign language students. Modern Language Journal, 72(3), 283-294. https://doi.org/10.1111/j.1540-4781.1988.tb04190.x

Humm, M. (1989). The Dictionary of Feminist Theory. Hertfordshire: Harvester Wheatsheaf.

Hunston, S., \& Thompson, G. (2000). Evaluation in text: Authorial stance and the construction of discourse. Oxford: Oxford University Press.

İnceçay, G. (2011). Pre-service teachers' language learning beliefs and the effects of these beliefs on their practice teaching. Procedia Social and Behavioral Sciences, 15, 128-133. https://doi.org/10.1016/j.sbspro.2011.03.061

Kinginger, C. (2004). Alice doesn't live here anymore: Foreign language learning and identity construction. In A. Pavlenko \& A. Blackledge (Eds.), Negotiation of identities in multilingual contexts (pp. 219-242). UK: Cromwell Press. https://doi.org/10.21832/9781853596483-010

Kumagai, K. (2013). How accent and identity influence each other: An investigation of L2 English speakers' perceptions of their own accents and their perceived social identities. M.A. Thesis. Retrieved from Knowledge Repository@ IUP. 
Kuntz, P. S. (1996). University students' beliefs about foreign language learning, with a focus on Arabic and Swahili at U.S. HEA Title VI African Studies Centers. Ph. D. dissertation. Madison, WI: University of Wisconsin, Department of Curriculum and Instruction.

Kuntz, P.S. (1996b). Students of “easy” languages: Their beliefs about language learning.

Labone, E., Cavanagh, P., \& Long, J. (2014). Critical design features of pre-service education programs to enhance teacher capacity to effectively work in schools with Indigenous students. The Australian Journal of Indigenous Education, 43, 121-133. https://doi.org/10.1017/jie.2014.22

Lattimer, H. (2012). Action research in pre-service teacher education: Is there value added? Inquiry in Education, 3(1).

Likert, R. (1932). A Technique for the Measurement of Attitudes. Archives of Psychology, 140, 1-55.

Lin, P. Y., Childs, R. A., \& Zhang, J. (2016). It takes a toll on pre-service teachers and programs: Case studies of teacher candidates who withdrew from a teacher education program. Cogent Education, 3(1). https://doi.org/10.1080/2331186X.2016.1160524

Lin, Y. (2007). The sounds of Chinese. Cambridge, UK: Cambridge University Press.

Macnamara, J. (1967). The bilingual's linguistic performance: A psychological overview. Journal of Social Issues, 23(2), 58-77. https://doi.org/10.1111/j.1540-4560.1967.tb00576.x

Maxwell, J. A. (2013). Qualitative research design: An interactive approach (3rd ed.). Thousand Oaks, CA: Sage.

Merino, I (1997). Native English-speaking teachers versus non-native English-speaking teachers. Revista Alicantina de Estudios Ingleses, 10, 67-79.

Mohanty, A. (1994). Bilingualism in a multilingual society: Psychological and pedagogical implications. Mysore: Central Institute of Indian Languages.

Mooi, L. M., \& Mohsin, M. (2014). How do Pre-service Teachers Develop Understanding of Student Learning through Action Research Project, Procedia-Social and Behavioral Sciences, 114, 877-882. https://doi.org/10.1016/j.sbspro.2013.12.801

Mori, Y. (1999). Epistemological beliefs and language learning beliefs: What do language learners believe about their learning? Language Learning, 49(3), 377-415. https://doi.org/10.1111/0023-8333.00094

Ng, E. (2015). Bilingualism, biliteracy, and cognitive effects: A review paper. University of Sydney Papers in TESOL, 10, 93-128.

Pacific Community Ventures. (2016). Defining and Measuring the Creation of Quality Jobs. Retrieved from: https://www.pacificcommunityventures.org/2016/04/14/defining-and-measuring-the-creation-of-quality-job $\mathrm{s} /$

Park, G.P. (1995). Language learning strategies and beliefs about language learning of university students learning English in Korea. Unpublished Doctoral Dissertation, The University of Texas at Austin, USA.

Patton, M. Q. (2002). Designing qualitative studies [excerpt: Purposeful sampling]. In Qualitative research and evaluation methods (3rd ed., pp. 230-247). Thousand Oaks, CA: Sage.

Patton, M. Q. (2015). Qualitative research \& evaluation methods: Integrating theory and practice (4th ed.). Thousand Oaks, CA: Sage.

Powell, R., \& Batters, J. (1985). Pupil's perceptions of foreign language learning at 12+: some gender differences. Educational Studies, 2(1), 11-23. https://doi.org/10.1080/0305569850110102

Richardson, S. (2016). The 'native factor'-the haves and the have-nots... and why we still need to talk about this in 2016. Plenary session presented at IATEFL Online, Birmingham, UK. Retrieved from: https://iatefl.britishcouncil.org/2016/session/plenary-silvana-richardson

Scamman, K. (2018). Spanish Speakers in the United States (Infographic). Retrieved from: https://telelanguage.com/spanish-speakers-united-states-infographic

Smith, A. (1976). Print. The Theory of Moral Sentiments. Oxfordshire: Clarendon.

Smith, S.H. (1989). Preliminary statistics of the BALLI with students learning Russian. Unpublished manuscript, University of Texas at Austin, USA. 
Soccorsi, L. (2013). Instilling a personal teaching philosophy in pre-service teachers: Vitally important but not always easy to achieve. Journal of Student Engagement: Education Matters, 3(1), 21-28.

Sunderland, J. (1998). Are girls being quiet: a problem for foreign language classrooms? Language Teaching Research, 2(1), 48-82. https://doi.org/10.1177/136216889800200104

Titone, R. (1972). Early bilingualism. Bruxelles: Charles Dessar.

Truitt. (1995). Beliefs about language learning: A study of Korean university students learning English. Texas Papers in Foreign Language Education, 2(1), 1-14.

Tsagari, D. (2009). The complexity of test washback: an empirical study. Frankfurt: Peter Lang.

Tumposky, N. R. (1991). Student beliefs about language learning: A cross-cultural study. Carleton Papers in Applied Language Studies, 8, 50-65.

Vinson, B. M. (2001). A comparison of preservice teachers' mathematics anxiety before and after a methods class emphasizing manipulatives. Early Childhood Education Journal, 29, 89-94. https://doi.org/10.1023/A:1012568711257

Weedon, C. (1987). Feminist Practice and Poststructuralist Theory. Oxford: Blackwell.

Woodcock, S., Hemmings, B., \& Kay, R. (2012). Does the study of an inclusive education subject influence pre-service teachers' concerns and self-efficacy about inclusion? Australian Journal of Teacher Education, 37(6), article 1. https://doi.org/10.14221/ajte.2012v37n6.5

Yang, N. D. (1992). Second language learners' beliefs about language learning and their use of learning strategies: A study of college students of English in Taiwan. Unpublished doctoral dissertation, University of Texas at Austin, USA. 


\section{APPENDIX A}

Below are beliefs that some people have about learning a second language. Read each statement and then decide if you: 1) Strongly Agree, 2) Agree, 3) Neither Agree nor Disagree, 4) Disagree, 5) Strongly Disagree. Questions 4 and 11 are different and should be marked as indicated. There are no right or wrong answers.

\begin{tabular}{|c|c|c|c|c|c|}
\hline Statement & SA & A & $\mathrm{N}$ & $\mathrm{D}$ & SD \\
\hline 1. It is easier for children than adults to learn a language. & 1 & 2 & 3 & 4 & 5 \\
\hline $\begin{array}{l}2 . \quad \text { Some people are born with a special ability which helps them learn a foreign } \\
\text { language. }\end{array}$ & 1 & 2 & 3 & 4 & 5 \\
\hline 3. Some languages are easier to learn than others. & 1 & 2 & 3 & 4 & 5 \\
\hline \multicolumn{6}{|l|}{$\begin{array}{l}\text { 4. The language I am planning to teach is 1) very difficult, 2) difficult, 3) } \\
\text { medium difficulty, 4) easy, 5) very easy. }\end{array}$} \\
\hline 5. It's important to speak a foreign with an excellent accent & 1 & 2 & 3 & 4 & 5 \\
\hline $\begin{array}{l}\text { 6. It is necessary to know the foreign culture in order to speak a foreign } \\
\text { language. }\end{array}$ & 1 & 2 & 3 & 4 & 5 \\
\hline 7. You shouldn't say anything in the language until you can say it correctly. & 1 & 2 & 3 & 4 & 5 \\
\hline $\begin{array}{l}\text { 8. It is easier for someone who already speaks a foreign language to learn } \\
\text { another. }\end{array}$ & 1 & 2 & 3 & 4 & 5 \\
\hline 9. It is better to learn a foreign language in the foreign country. & 1 & 2 & 3 & 4 & 5 \\
\hline 10. It's ok to guess if you don't know a word in the foreign language. & 1 & 2 & 3 & 4 & 5 \\
\hline $\begin{array}{l}\text { 11. If someone spent one hour a day learning a language, how long would it take } \\
\text { to become fluent? }\end{array}$ & 1 & 2 & 3 & 4 & 5 \\
\hline $\begin{array}{l}\text { 12. Learning a foreign language is mostly a matter of learning a lot of new } \\
\text { vocabulary words. }\end{array}$ & 1 & 2 & 3 & 4 & 5 \\
\hline 13. It's important to repeat and practice a lot. & 1 & 2 & 3 & 4 & 5 \\
\hline $\begin{array}{l}\text { 14. If you are allowed to make mistakes in the beginning, it will be hard to get rid } \\
\text { of them later on. }\end{array}$ & 1 & 2 & 3 & 4 & 5 \\
\hline $\begin{array}{l}\text { 15. Learning a foreign language is mostly a matter of learning a lot of grammar } \\
\text { rules. }\end{array}$ & 1 & 2 & 3 & 4 & 5 \\
\hline 16. It's important to practice in the language laboratory & 1 & 2 & 3 & 4 & 5 \\
\hline 17. Women are better than men at learning foreign languages & 1 & 2 & 3 & 4 & 5 \\
\hline 18. It is easier to speak than understand a foreign language. & 1 & 2 & 3 & 4 & 5 \\
\hline 19. Learning a foreign language is different from learning other school subjects. & 1 & 2 & 3 & 4 & 5 \\
\hline 20. Learning another language is a matter of translating from your first language. & 1 & 2 & 3 & 4 & 5 \\
\hline $\begin{array}{l}\text { 21. If students learn to speak a second language very well it will help them get a } \\
\text { good job. }\end{array}$ & 1 & 2 & 3 & 4 & 5 \\
\hline 22. It is easier to read and write a language than to speak and understand it. & 1 & 2 & 3 & 4 & 5 \\
\hline $\begin{array}{l}\text { 23. People who are good at math and science are not good at learning foreign } \\
\text { languages. }\end{array}$ & 1 & 2 & 3 & 4 & 5 \\
\hline 24. U.S. citizens think that it is important to speak a foreign language. & 1 & 2 & 3 & 4 & 5 \\
\hline 25. People who speak more than one language well are very intelligent. & 1 & 2 & 3 & 4 & 5 \\
\hline 26. Americans are good at learning foreign languages. & 1 & 2 & 3 & 4 & 5 \\
\hline 27. Everyone can learn to speak a foreign language. & 1 & 2 & 3 & 4 & 5 \\
\hline
\end{tabular}

\section{Copyrights}

Copyright for this article is retained by the author(s), with first publication rights granted to the journal.

This is an open-access article distributed under the terms and conditions of the Creative Commons Attribution license (http://creativecommons.org/licenses/by/4.0/). 